\title{
Social changes and challenges in (post-)pandemic times for social professions
}

„Social changes and challenges in (post-)pandemic times“ was the title of an event hosted and organized by the International Office of the Protestant University of Aplied Science in Bochum (EvH) and the Transfernetzwerk Soziale Innovation on June 17, 2021. Participants from three continents took part in the international exchange. The event took place via Zoom and YouTube in English and with translation for German contributions. Speakers from Germany, Kurdistan Region of Iraq, South Africa and Russia addressed the topic from their perspectives. The structure of this contribution is analogous to the event. First, the relevance of the issue is introduced before the speakers present the challenges and solutions of their respective countries and regions. Finally, some similarities and differences that became apparent through the contributions and the following discussion are outlined.

\section{Introductory Framing}

Cinur Ghaderi, Vice Chancellor for Research, Transfer and Internationalization from Protestant University of Aplied Science in Bochum mentioned that numerous social challenges go hand in hand with the pandemic. On a personal level, people in Corona times had to contend with declining or even disappearing incomes, and on a global level, too, economic bottlenecks and social conflicts confronted entire economic systems with profound changes. The consequences of the pandemic have increased the vulnerability of many people. For example, according to a study by the International Monetary Fund (2021), food prices rose by about $25 \%$ worldwide in the Corona year, the highest in more than a decade. Rising prices are hitting a pandemic-related global economy in crisis: incomes are falling, global supply chains are threatened by lockdown measures, and many are unable to pursue their jobs. People with already low incomes are particularly at risk from rising prices. There is concern about a toxic combination of Covid-19, climate change and social unrest.

Prof. Dr. Kristin Sonnenberg, who moderated the event, formulated the following key questions, which were illuminated by the digital format in an international perspective: What social inequalities have emerged or become more visible as a result of the pandemic? What questions and needs arise from this for the social professions in social and health care and nursing? Where are there helpful, inspiring approaches or projects? 


\section{Germany}

The situation in Germany was described by Rector of Protestant University of Aplied Science in Bochum, Prof. Dr. Dr. Sigrid Graumann. From the perspective of this member of the German Ethics Council, a general easing of the situation can be observed after the third wave of the pandemic in Germany in the past six months, which has been the most severe to date. The number of infections in spring/summer 2021 and especially the number of patients in hospitals and intensive care units had been decreasing continuously. The proportion of the population with at least the first vaccination has currently reached $60.6 \%$. Free rapid tests are available nationwide. Schools and day-care centres are open again on a regular basis. At universities, at least individual seminars and courses are being attended again. Shops and restaurants are open again with protective concepts, the first cultural events are taking place again, travelling has become easier and life is increasingly returning to normal.

The societal consequences of the pandemic will need to be addressed in the longer term based on lessons learned. With a total population of about 84 million, there were about 3.7 million confirmed cases. But, almost 90,000 people have died in Germany from or with Covid-19. These figures are good in European comparison. But it has been shown that while the German economy is strong and the loss of income has been at least partially compensated, the health, social and education systems were not well prepared for the crisis. Germany has a very high number of beds in intensive care units compared to other countries. Nevertheless, there were bottlenecks due to a lack of nursing staff. Due to cost-cutting measures in the public health sector, effective tracking of infection chains was not possible. The organisation of the vaccination campaign was rather chaotic. Ethically based prioritisation rules, which had been established by the Robert Koch Institute, the National Academy of Science (Leopoldina) together with the German Ethics Council, were insufficiently followed. Particularly vulnerable groups, such as the homeless and refugees, were vaccinated only very late because strong groups were able to assert themselves. Initially, there was not enough protective equipment such as masks. Health and social workers had to work unprotected. Many of them and their clients became infected. It was particularly bad in the care sector: more than half of the dead were residents of nursing homes. To prevent infections in the nursing homes and homes for the disabled, but also in the refugee shelters, the residents were more or less isolated for many months. Psychological stress and damage, but also damage to the health of those affected, are the result.

Initially, it was said that the whole of society was affected by the pandemic. Gradually, however, it is becoming clear that social status plays a major role: most well-paid workers worked at home and were thus able to protect themselves from infection. In contrast, many occupational groups that provide care and other important services to the population, such as shop assistants and parcel delivery workers, but also nurses and social workers, not only earn little, but are also poorly able to protect themselves from infection. The 
closure of schools and day-care centres has placed a heavy burden on families. The consequences are an increase in domestic violence, developmental deficits and psychological damage to children and adolescents. In general, it has been shown that social inequalities not only show up in the pandemic, but are even exacerbated. Coercive measures in psychiatry have increased. There are reports from doctors that an above-average number of migrants have been affected by severe courses of illness. Homeschooling has worked much better for pupils from socially better-off families who have a quiet place to study and are supported by their parents than for children from socially weaker families whose parents work away from home and who live in cramped conditions, or children and young people who live in a refugee shelter in cramped rooms with their family without access to wifi. The educational inequalities are thus massively reinforced.

There is still no clear and complete picture of the pandemic and its consequences. It will be a great challenge for the social and health sciences to explore this. In any case, there is a great need for reforms in the social, health and education systems to make them crisis-proof. In general, the public sector needs to be strengthened, made more efficient and flexible. More care workers are needed, who deserve social recognition and must be adequately paid. Programmes are needed to compensate for learning deficits among children and young people, but above all to strengthen their mental health. And last but not least, social inequality must be fought, because the crisis has shown that it endangers social cohesion and political stability even in a country as rich as Germany.

\section{Kurdistan Region of Iraq}

Ass. Prof. Dr. Luqman Karim from University of Sulaimani, reported on the situation in the Kurdistan Region of Iraq. A historical turning point is emerging: the time before and after Corona. In Iraq, 20,000 people have died from Covid-19, in addition to 4,500 deaths in the Kurdish Region in Iraq. These numbers exceed the number killed in the Islamic State (IS) war. There is a widening inequality between classes in the Kurdistan Region of Iraq. In a region that is economically and politically unstable, where the lockdown not only disrupts freedom of movement but above all economic activity, where salaries are restricted by political conflict and central government budget cuts, where there is no universal health insurance but a high rate of corruption, inequality has increased significantly. There is a division between those who have access to private hospitals and the vaccine due to their wealth, and those who cannot protect themselves due to their poorer financial situation, as they do not have access to the vaccine and simply cannot afford to stay at home and not work. In the field of social professions and health authorities, there are many issues that need to be explored at present and in the future. These are, for example: what demands on professional social work arise from the crisis? What are the implications of Corona for family and gender issues? How have the frequency of occurrence of different forms of gender-based violence 
changed? How can threats of honour killings, physical and verbal violence from a distance be professionally prevented? What are the consequences at the institutional level of social organisation? How can cases of violence be managed from a distance? Due to the family and social situation, it can be difficult for survivors of violence against women to access services, as the pandemic has made it even more difficult for them to move around and access life-saving services. Therefore, social workers had to familiarise themselves with remote case management (OCHA, 2021), e.g. by explaining to women affected by violence how they can get more data security by deleting their messages for their protection. A multidisciplinary approach seems appropriate for this task as well as a close integration of science and practice to grasp the psychological, social and familial effects of the Corona crisis.

\section{South Africa}

Dr. Ingrid Daniels from Cape Mental Health in Cape Town presentetd the situation in South Africa. An increase in inequalities was also observed there. The economic and mental health consequences of the Covid-19 lockdown measures impacted mainly on underserved and poverty-stricken communities. There was an alarming increase in common mental disorders, especially due to social determinants such as rising unemployment, reduced incomes, sharp increases in impoverishment, economic inequality and the increase in gender-based violence.

The pandemic highlighted the extreme levels of poverty and lack of resources to meet the basic needs of children and adults. These inequalities were also evident in the emergency health and social response to Covid-19, as fragile health systems were unable to cope with large populations of infected people relying solely on public health care. Low- and middle-income countries remained at a disadvantage, unable to purchase large quantities of the vaccine, and left in the wake and rush for global population immunity to the virus. In the current and post-covid-19 environment, social and health professionals need to question their relevance, practice and capacity to transform their interventions to adequately address the negative impact of the pandemic on communities and families.

Despite the challenges and initial dislocations in social and health care, critical best practice interventions have emerged. The pandemic created the opportunity to shift, reinvent and reorganise the way in which Cape Mental Health provided mental health care from facility to home and face to face counselling to virtual interventions to retain contact, reduce isolation and continue virtual interactions with beneficiaries and all who required mental health support. Cellular phone applications, virtual IT technology and other platforms became vital tools for migrating daily mental health services remotely to over 6,000 beneficiaries. Online counselling, Covid-19 crisis and case management were provided by a dedicated team of social workers. Another example of the daily virtual activations, at Special Education and Care Centres for children with severe and profound intellectual disability, were identified 
as the best practice mental health innovation during the Covid-19 pandemic by the Mental Health Innovations Network (Cape Mental Health, 2021).

Interventions by social and health professionals need to be revised and an exchange on further innovative alternatives stimulated to address some of the huge inequalities. The mental health of social professionals plays an important role in this: we heal by coming together.

\section{Russia}

The situation in Russia was presented by Dr. Ekaterina Tikhomirova from Vologda State University in Russia, where, too, the pandemic challenged the state, society and every individual. The economic consequences affected sectors differently. Medium-sized enterprises in tourism, hotel business, gastronomy, public transport, household services, fitness, etc., whose activities were halted for a long time and then limited, were more economically vulnerable, while students, ordinary employees and pensioners were in a more stable position due to regular wages, pensions or scholarships.

Social and health care professionals are ready and willing to adapt to the changed conditions of service delivery, to come to the aid of those in need and even to risk their own health in the process. Trust between governmental and non-governmental social service providers has grown during the crisis. Due to the pandemic, the usual working formats of social services in Russia changed overnight as people had increased needs, could not wait and in some cases were not allowed to leave their homes. In many areas, there was a shift to online interaction. However, in social work there are areas where it is impossible to act remotely, mainly the activities of specialised social service institutions where clients live permanently (psychoneurological boarding schools, nursing homes, etc.), and home care for the elderly and disabled.

Older people are heavily affected in Russia and thus an increase in mental illness, dementia and other diseases could be observed in social communication. This highlighted the importance of psychological support at a distance, keeping in touch with relatives and communicating with friends.

The issue of loneliness is particularly noteworthy. The problem of social loneliness has intensified: elderly people confined to four walls, often unable to use modern gadgets, just wanted to talk to someone. Thus, the need to create special telephone lines for such people appeared in social services. In some centres, volunteers were called in to do this work, talking to lonely elderly people from their homes through their personal phones. For those elderly and people with disabilities who can use modern gadgets, online platforms for communication were created: Chat rooms in WhatsApp, Telegram, groups in social networks, etc. Videos with movement exercises by specialists in therapeutic physical culture, video conferences with doctors, representatives of pension funds and other specialists, became very popular among older people.

The problem of social loneliness led to the need for psychological support in quite a large area. It turned out that not all psychologists know how to 
provide psychological help at a distance, in most cases by telephone when the client and the counsellor do not see each other. This led to the need to teach psychologists the specifics of providing psychological help at a distance.

Another new challenge for the social services system: for lonely people aged $65+$ who were not allowed to go out of the house, the problem of walking dogs appeared. Pets are significant for lonely old people, but also for all owners for their mental and physical health. A way out was found through the involvement of volunteers, for example the neighbours of the owner of the dog, representatives of animal welfare organisations or students who walked the dogs.

Looking back, the main conclusions about the results of 15 months of social work in Russia in the conditions of the coronavirus pandemic are: firstly, that participatory, not indifferent people are needed who remain faithful to their professional ethics. Secondly, to note the trustful cooperation between the state and non-state social service agencies, socially oriented nonprofit organizations. Thirdly, the power of the voluntary movement to solve social problems became evident. Thus, voluntary centres were created in every locality, thanks to which it became possible to relieve the organisation of social welfare from most of the work „on call“ by people in the 65+ category. These are delivery of products, medicines, dog walking, organising communication. Fourthly, in the pandemic conditions, it is necessary to take care not only of the health indicators of the elderly, but also of their social communication, for which it is necessary to carry out training in work with communication technology. It is no secret that the pandemic caused the increase of mental illnesses all over the world, so examples of distance psychological support, maintaining connection with relatives, communication with friends, are very important.

\section{Similarities and differences, convergences and divergences}

The Corona pandemic has affected neither all countries, nor all social groups in the respective societies, nor all professional sectors equally. At the same time, the commonalities of all regional reports are that a) social inequality has worsened and become more visible, b) gender-based violence and domestic violence have increased, c) isolated conditions are a major issue and d) numerous challenges for social and mental health systems have emerged. These commonalities have had an impact on the social and health professions in the pandemic, and have led to the following challenges, among others:

- The requirement to build and maintain trusting, honest and empathic relationships by phone or internet while maintaining privacy and confidentiality, or in person with protective clothing. Competences in remote case management, which were previously more common to social workers working e.g. in emergency call centres, became general competence expectations.

- The task of prioritising the needs and demands of users/addressees, which have increased and changed due to the pandemic - with expanded resources often unavailable and full assessments of need often impossible. 
- The need to balance the rights, needs and risks of users/addressees against personal risks for social workers and others in order to provide necessary support/interventions as best as possible.

- Acknowledgement and management of emotions, fatigue and the need for self-care when professionals are working in uncertain and stressful circumstances.

The pandemic and its aftermath has created discomfort, it has challenged everyone to find different ways through the new uncertainties woven into daily life and work. The changes challenge certainties and habits and require drawing lessons from the work during the pandemic to rethink the work of social and health care professionals in the future. It can be an opportunity to creatively change professional practices, for example, or to think about virtual possibilities for psychosocial work. I.e. the pandemic has not only created global social and professional challenges, but also space for opportunities and innovations, it has shown, among other things, how increasing digitalisation brings society together and networks it globally. If necessary, this can be an opportunity to understand social and health issues more globally and to ask how the problems in particularly vulnerable contexts, for example in connection with flight, hunger or burdened health systems, can be managed. With all the brutality, there is a growing awareness of how interconnected people are on this one planet. It becomes apparent that global consequences of the pandemic can only be countered through cooperation and collaboration, in the self-image of its responsible, global community.

Revealing at this time are grassroots, how people solve upcoming problems. The power of the voluntary movement and social engagement to solve social problems was evident in all countries represented. The pandemic and related challenges and problems affect all human beings and highlight the importance of addressing and finding solutions together. For the pandemic and the catastrophe and global crisis it has caused, requires solidarity, joint action, mutual mindfulness and support to face the suffering and loss. A good foundation for a cooperative exchange was laid in this event.

\section{Cinur Ghaderi, Kristin Sonnenberg, Sigrid Graumann, Luqman Saleh Karim, Ingrid Daniels, Ekaterina Tikhomirova}

\section{Sources}

Cape Mental Health (2021). Retrieved on 6 Nov 2021 from https://www.mhinnovation.net/ organisations/cape-mental-health

International Monetary Fund (2021). World economic outlook: managing divergent recoveries, Washington, DC: IMF.

OCHA (2021). Retrieved on 6 Nov 2021 from https://www.humanitarianresponse.info/en/operations/iraq/document/gbv-case-management-guidance-note-during-covid-19-outbreak-iraq 



\section{Spoštovani!}

Socialne delavke in delavce, uporabnice in uporabnike socialnih služb, strokovnjakinje in strokovnjake, raziskovalke in raziskovalce socialnega dela in drugih področij družbenega delovanja, političarke in politike, delavke in delavce $v$ medijih ter druge zainteresirane posameznice in posameznike vabimo k prijavi prispevkov za 8. kongres socialnega dela, ki bo potekal 16. in 17. novembra 2022 v Termah Zreče, Hotel Vital.

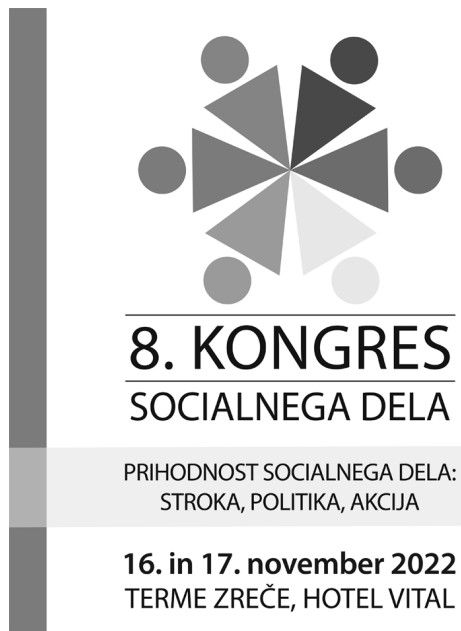

Osmi kongres socialnega dela se zaradi novih izzivov, ki jih je povzročila pandemija virusa covid-19, vrača na vnovično spraševanje o vlogi in nalogah socialnega dela v izrednih pa tudi drugih okoliščinah v družbi. Ob pomembnih že znanih izzivih (kot so revščina, socialna izključenost, nasilje, migracije, prekarizacija, medijski napadi, vse večja birokratizacija na posameznih področjih), ki smo jih na preteklih kongresih že obravnavali, so se leta 2020 v ospredje prebili novi izzivi, na primer veliko povečanje nasilja $v$ družini, še večja neenakost, popolna izolacija nekaterih družbenih skupin, izražanje želja po privatizaciji javnega sektorja, omejevanje izobraževanja in raziskovanja. Ti izzivi so nas po eni strani opomnili na veliko povezanost in medsebojno odvisnost celotne družbe (tako na ravni posameznikov kot tudi strok in znanosti), na drugi pa pokazali na velik pomen dobrega medsebojnega (so)delovanja tako za ohranjanje pomena stroke socialnega dela kot tudi za širšo družbeno korist. Organizatorji kongresa smo prepričani, da ima lahko socialno delo ključno vlogo gibala in povezovalnega člena med udeleženimi akterji na omenjenih področjih delovanja znotraj in onkraj slovenskih meja.

Podrobnejšo najavo kongresa in prijavi obrazec najdete na:

\section{www.fsd.uni-lj.si/kongres}

Kongres organizirata Fakulteta za socialno delo Univerze v Ljubljani in Društvo socialnih delavk in delavcev Slovenije

Prijave prispevkov bodo odprte do 15. 1. 2022

Vabljeni!

Doc. dr. Bojana Mesec in doc. dr. Liljana Rihter

Predsednici programskega izvršnega odbora

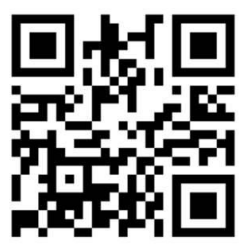




\section{CALL FOR CONTRIBUTIONS}

Dear colleagues,

Faculty of Social Work, University of Ljubljana and Association of Social Workers of Slovenia are happy to announce the $8^{\text {th }}$ Congress of Social Work: "Future of Social Work: Profession, Politics, Action" and you are heartily welcome to participate. It will take place on the $16^{\text {th }}$ and $17^{\text {th }}$ of November 2022 in Terme Zreče, Slovenia.

You can find more information at the web page:

\section{www.fsd.uni-lj.si/kongres}

With best wishes,

For the programme committe,

Bojana Mesec, PhD and Liljana Rihter, PhD

Faculty of Social Work, University of Ljubljana 